\title{
Dispersal Ability and Genetic Structure in Mytilid Mussels of Whale-Fall Communities
}

\author{
Youki Fukasawa1, Haruna Kobayashi-Iwatani², Masaru Kawato3, Hideki Kobayashi, \\ Yoshihiro Fujiwara ${ }^{3}$, Jun-Ichi Miyazaki2* \\ ${ }^{1}$ Graduate School of Medical and Engineering Science Department of Education, University of Yamanashi, \\ Kofu, Japan \\ ${ }^{2}$ Faculty of Education and Human Sciences, University of Yamanashi, Kofu, Japan \\ ${ }^{3}$ Department of Marine Biodiversity Research, Japan Agency for Marine-Earth Science and Technology, \\ Yokosuka, Japan \\ ${ }^{4}$ Department of Environmental Geochemical Cycle Research, Japan Agency for Marine-Earth Science and \\ Technology, Yokosuka, Japan \\ Email: miyazaki@yamanashi.ac.jp
}

Received 6 May 2015; accepted 19 July 2015; published 23 July 2015

Copyright (C) 2015 by authors and Scientific Research Publishing Inc.

This work is licensed under the Creative Commons Attribution International License (CC BY).

http://creativecommons.org/licenses/by/4.0/

(c) (i) Open Access

\section{Abstract}

Since organic falls are ephemeral and distributed sporadically, organisms in organic-fall communities must acquire high dispersal ability to migrate from one organic fall to another. However, the dispersal ability of obligate organic-fall organisms has not been investigated thoroughly and the stability of the genetic structure of their communities is unknown. In this study, in order to elucidate the dispersal ability and genetic structure in the organic-fall communities, we carried out population genetic analyses based on sequences of mitochondrial NADH dehydrogenase subunit 4 in two mytilid mussels. Adipicola pacifica was obtained from whale and cow bones artificially settled in Japanese waters off Cape Noma (CN) and in the Nansei-Shoto Trench (NS) and Sagami Bay (SB), and Benthomodiolus geikotsucola from natural whale bones in the Torishima Seamount (TS); both species are symbiotic with chemoautotrophic bacteria. Genetic differentiation $\left(F_{\text {st }}\right)$ indicated almost no annual change in genetic structure between 2003, 2004, 2005, and 2007 collections of $A$. pacifica from CN (depth 225 - $229 \mathrm{~m}$ ), although the 2010 collection had somewhat different genetic structure from the others. Similarly, there was not significant genetic differentiation between 1993 and 2005 collections of B. geikotsucola from TS (depth 4020 m). The $F_{\text {st }}$ and gene bidirectional mean rate of gene flow $(\mathrm{Nm})$ indicated high gene flow and no significant genetic differentiation between $A$. pacifica specimens collected from CN, NS, and SB. The results suggest that the genetic structure is stable and $A$. pacifica has high dispersal ability. The mismatch distribution suggests that $A$. pacifica expanded their distribution from SB to NS via $\mathrm{CN}$, as expansion time ( $\tau=$ 2ut) decreased from SB to CN and NS.

"Corresponding author.

How to cite this paper: Fukasawa, Y., Kobayashi-Iwatani, H., Kawato, M., Kobayashi, H., Fujiwara, Y. and Miyazaki, J.-I. (2015) Dispersal Ability and Genetic Structure in Mytilid Mussels of Whale-Fall Communities. Open Journal of Marine Science, 5, 295-305. http://dx.doi.org/10.4236/ojms.2015.53025 


\section{Keywords}

\section{Chemosynthesis-Based Community, Mitochondrial DNA, Organic Falls, Stepping Stone Hypothesis}

\section{Introduction}

The chemosynthetic community at a hydrothermal vent was found along the Galapagos Rift in 1997 [1] [2]. In the 1980s, similar communities were discovered on a seep in the Gulf of Mexico [3] [4] and on whale bones at the Santa Catarina Basin [5]. Primary production in these communities depends on chemosynthetic bacteria, which obtain energy by oxidation of methane and hydrogen sulfide that are emitted from vents and seeps. Hydrogen sulfide is also generated by anaerobic bacterial decomposition of whale carcasses and sunken wood. Whale carcasses experience ecological succession: mobile-scavenger stage, enrichment opportunist stage, sulphophilic stage, and reef stage. Many unique animals constituting the chemosynthetic community have been found at the sulphophilic stage [6]. In Japanese waters off Cape Noma near Kagoshima Bay (depth 225 - 229 m), artificially set bones of the sperm whale, Physeter sp., were covered by mytilid mussels Adipicola pacifica and A. crypta [7]. Investigations of the whale-fall community have been performed by the Japan Agency for Marine-Earth Science and Technology (JAMSTEC) as reported by Fujiwara et al. [8]. The chemosynthetic community established on natural bones of Bryde's whale, Balaenoptera brydei, has been observed at the Torishima Seamount (depth $4020 \mathrm{~m}$ ) [9]. A new species of mytilid mussel Benthomodiolus geikotsucola, which harbored thioautotrophic bacteria, was described from the whale bones [10].

Vents last less than a few decades, whereas seeps persist for comparatively longer period [11]. Thus, animals must migrate from one vent to another that is sometimes many thousand kilometers away. Two deep-sea mytilid mussels, Bathymodiolus japonicus and Ba. platifrons, inhabiting vents in the Okinawa Trough and seeps in Sagami Bay off Japan [12], were shown to have high dispersal abilities, as indicated by the lack of genetic differences between the individuals inhabiting the vents and seeps [13]. The high dispersal ability was also suggested in three vent mytilid mussels, Ba. marisindicus, Ba. brevior, and Ba. septemdierum [14]. High gene flow and low genetic divergence existed between Ba. septemdierum from the Izu-Ogasawara Islands-arc and Ba. brevior from the North Fiji Basin, although their habitats are $5000 \mathrm{~km}$ apart. Furthermore, perceptible but not high gene flow between $B a$. septemdierum and Ba. marisindicus from the Southern Central Indian Ridge and between $B a$. brevior and $\mathrm{Ba}$. marisindicus was shown, although their habitats are almost $10000 \mathrm{~km}$ apart.

Smith et al. [5] proposed that organic falls act as stepping stones that connect chemosynthetic communities, but only a few species are shared between organic-fall and deep-sea vent/seep communities [6]. In contrast, the "evolutionary stepping stone hypothesis" [15] was supported by studies of mytilid mussels [16] [17]. According to this hypothesis, shallow-water animals utilized organic falls as stepping stones to colonize deep-sea vents and seeps. For adaptation to deep-sea environments, animals must acquire tolerance to toxic hydrogen sulfide and methane, high hydrostatic pressure, and low water temperature. They also have to modify feeding strategies or acquire new ones to get energy under the deep-sea conditions of poor nutrient availability due to lack of photosynthesis. Since whale bones and sunken wood are sporadically available from shallow to deep waters, this hypothesis can explain how animals evolutionarily acquired the tolerance and developed feeding strategies. Furthermore, organisms must acquire high dispersal ability to exploit patchy and ephemeral deep-sea habitats. We hypothesize that high dispersal ability was also facilitated by organic falls. Dispersal ability of mytilid mussels in the chemosynthetic community of organic falls has been investigated poorly until now. Thus, it is not known where these organisms come from when colonizing organic falls and how they migrate from one organic fall to another. Moreover, it is not known whether genetic structure of mytilid mussels in a community is stable or perturbed. The stability of genetic structure seems to closely correlate with the dispersal ability.

The purpose in this study is to evaluate dispersal ability and stability of genetic structure of organic-fall mytilids by population genetic analyses of the sequences of the mitochondrial NADH dehydrogenase subunit 4 (ND4) gene. First, we indicate annual changes of genetic structures of whalebone-associated mytilid mussels, A. pacifica and B. geikotsucola obtained from CN and TS, respectively. Next, we indicate genetic differentiation and gene flow among specimens of A. pacifica from CN, NS, and SB. Finally, we discuss dispersal ability of organic-fall mytilids to test our hypothesis that high dispersal ability was acquired in organic falls to colonize deep sea. 


\section{Materials and Methods}

\subsection{Materials}

Specimens used in this study are listed in Table 1 and collection sites are mapped in Figure 1. Mussels were collected from whale bones located in CN (depth 225 - $229 \mathrm{~m}$ ), TS (depth $4020 \mathrm{~m}$; the depth was recorded at $4051 \mathrm{~m}$ in 1992 and at $4020 \mathrm{~m}$ by novel bathymetry in 2005), and SB (depth $399-491 \mathrm{~m}$ ), and from cow bones in NS (depth 501 and 502 m) by submersibles, "Kaiko 7000 II", "Hyper-Dolphin 3000", and "Shinkai 6500" operated by JAMSTEC. Whale and cow bones were artificially settled in CN, SB, and NS ([8] and JAMSTEC cruise reports, NT12-22, NT13-06, NT10-07 leg 1, and KR12-01) and natural whale bones in TS were found in 1992 [18] [19]. We used 20 specimens of A. pacifica each from 2003, 2004, 2005, 2007, and 2010 collections of CN and 20 specimens from 2010 and 2012 collections of NS, and eight specimens from 2012 and 2013 collections of SB for population genetic analyses. Because of small number of samples, 2010 and 2012 collections from NS were combined together, as well as those from 2012 and 2013 collections from SB. Additionally, we used 20 specimens of B. geikotsucola each from 1993 and 2005 collections of TS. All samples were frozen and preserved at $-80^{\circ} \mathrm{C}$ or preserved in $100 \%$ ethanol, and deposited at JAMSTEC.

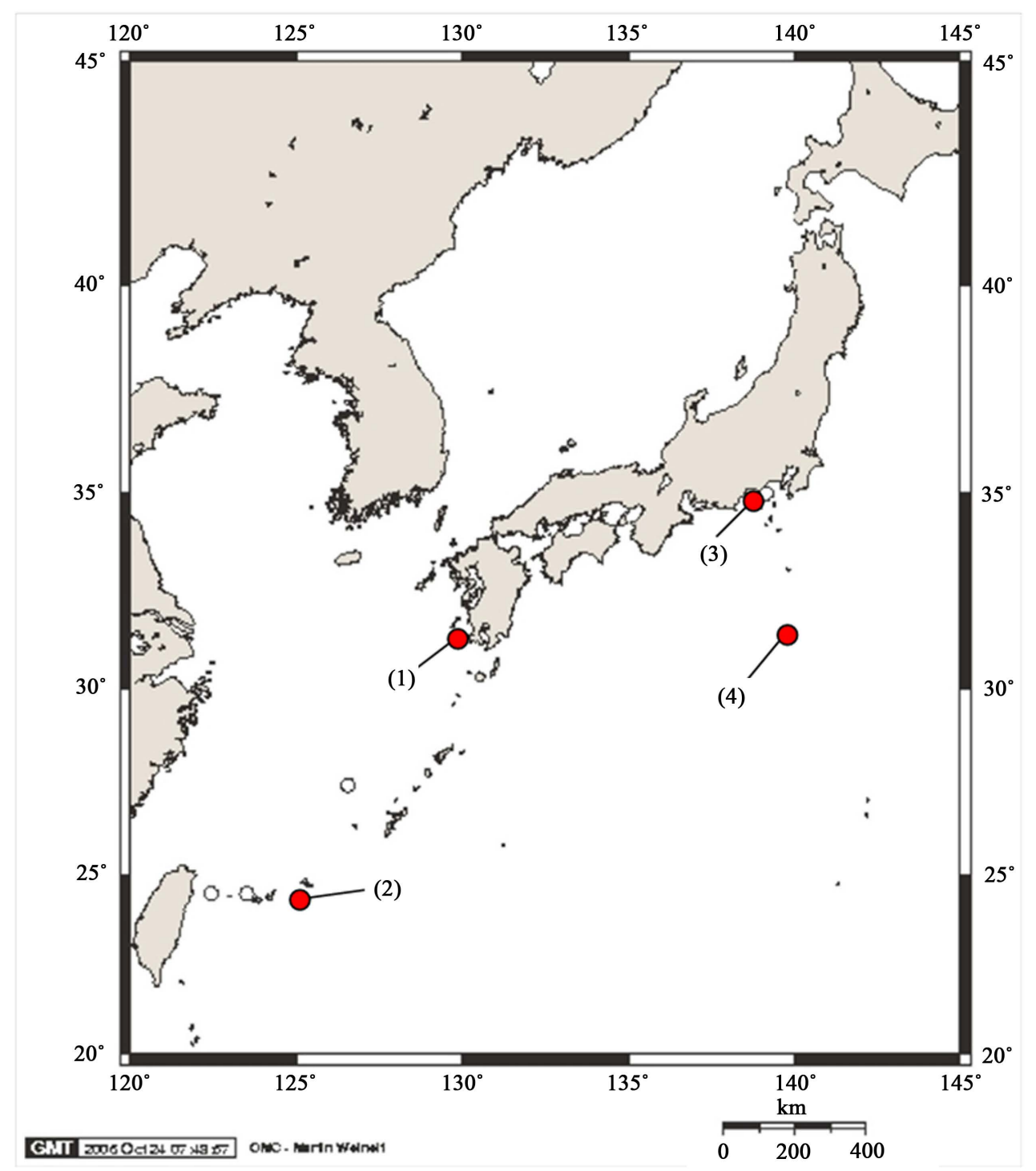

Figure 1. Location of sampling sites. (1) off Cape Noma; (2) Nansei-Shoto Trench; (3) Sagami Bay; (4) Torishima Seamount. 
Table 1. List of samples and voucher data.

\begin{tabular}{|c|c|c|c|c|c|c|}
\hline Sample & Sample abbreviation & Sampling site & Habitat & Depth & Location & Dive number \\
\hline & $\begin{array}{l}\text { (the number of } \\
\text { specimens) }\end{array}$ & \multicolumn{2}{|c|}{ (locality number in Figure 1) } & $(\mathrm{m})$ & & \\
\hline \multicolumn{7}{|c|}{ Adipicola pacifica } \\
\hline \multirow[t]{3}{*}{2003} & APN301-302 (2) & Off Cape Noma (1) & Whale bone & 229 & $31^{\circ} 20.72^{\prime} \mathrm{N} ; 129^{\circ} 59.29^{\prime} \mathrm{E}$ & HPD\#189 \\
\hline & APN303-304 (2) & Off Cape Noma (1) & Whale bone & 228 & $31^{\circ} 21.00^{\prime} \mathrm{N} ; 129^{\circ} 59.16^{\prime} \mathrm{E}$ & HPD\#191 \\
\hline & APN305-320 (16) & Off Cape Noma (1) & Whale bone & 229 & $31^{\circ} 20.72^{\prime} \mathrm{N} ; 129^{\circ} 59.29^{\prime} \mathrm{E}$ & HPD\#192 \\
\hline 2004 & APN401-420 (20) & Off Cape Noma (1) & Whale bone & 225 & $31^{\circ} 20.72^{\prime} \mathrm{N} ; 129^{\circ} 59.29^{\prime} \mathrm{E}$ & HPD\#328 \\
\hline \multirow[t]{2}{*}{2005} & APN501-503 (3) & Off Cape Noma (1) & Whale bone & 230 & $31^{\circ} 20.992^{\prime} \mathrm{N} ; 129^{\circ} 59.156^{\prime} \mathrm{E}$ & HPD\#452 \\
\hline & APN504-520 (17) & Off Cape Noma (1) & Whale bone & 229 & $31^{\circ} 20.721^{\prime} \mathrm{N} ; 129^{\circ} 59.288^{\prime} \mathrm{E}$ & HPD\#453 \\
\hline 2007 & APN701-720 (20) & Off Cape Noma (1) & Whale bone & 226 & $31^{\circ} 20.725^{\prime} \mathrm{N} ; 129^{\circ} 59.29^{\prime} \mathrm{E}$ & HPD\#682 \\
\hline \multirow[t]{2}{*}{2010} & APN1001-1020 (20) & Off Cape Noma (1) & Whale bone & 229 & $31^{\circ} 35.00^{\prime} \mathrm{N} ; 129^{\circ} 59.16^{\prime} \mathrm{E}$ & HPD\#1123 \\
\hline & APO1-16 (16) & Nansei-Shoto Trench (2) & Cow bone & 502 & $24^{\circ} 45.006^{\prime} \mathrm{N} ; 125^{\circ} 45.048^{\prime} \mathrm{E}$ & HPD\#1112 \\
\hline \multirow[t]{2}{*}{2012} & APO17-20 (4) & Nansei-Shoto Trench (2) & Cow bone & 501 & $24^{\circ} 45.0029^{\prime} \mathrm{N} ; 125^{\circ} 45.0495^{\prime} \mathrm{E}$ & KAIKO\#0528 \\
\hline & APS1 (1) & Sagami Bay (3) & Whale bone & 399 & $35^{\circ} 04.485^{\prime} \mathrm{N} ; 139^{\circ} 07.566^{\prime} \mathrm{E}$ & HPD\#1428 \\
\hline \multirow[t]{2}{*}{2013} & APS2-4 (3) & Sagami Bay (3) & Whale bone & 401 & $35^{\circ} 04.480^{\prime} \mathrm{N} ; 1^{\circ} 9^{\circ} 07.572^{\prime} \mathrm{E}$ & HPD\#1501 \\
\hline & APS5-8 (4) & Sagami Bay (3) & Whale bone & 491 & $35^{\circ} 05.576^{\prime} \mathrm{N} ; 139^{\circ} 10.271^{\prime} \mathrm{E}$ & HPD\#1504 \\
\hline \multicolumn{7}{|c|}{ Bathymodiolus geikotsucola } \\
\hline 1993 & BGT101-120 (20) & Torishima Seamount (4) & Whale bone & 4051 & $30^{\circ} 54.90^{\prime} \mathrm{N} ; 141^{\circ} 49.20^{\prime} \mathrm{E}$ & $6 \mathrm{~K} \# 174$ \\
\hline 2005 & BGT201-220 (20) & Torishima Seamount (4) & Whale bone & 4020 & $30^{\circ} 55.10^{\prime} \mathrm{N} ; 141^{\circ} 49.00^{\prime} \mathrm{E}$ & 6K\#895 \\
\hline
\end{tabular}

\subsection{Sequencing of the Mitochondrial ND4 Gene}

Sequencing was performed essentially as described previously [13]. Total DNA was prepared from the soft tissue using a DNeasy ${ }^{\circledR}$ Blood \& Tissue Kit (QIAGEN GmbH, Hilden, Germany) according to the manufacturer’s protocol.

To amplify partial fragments of ND4 in A. pacifica (491 bp) and in B. geikotsucola (402 bp), PCR was performed in reaction solutions containing template DNA and KOD Dash (Toyobo Co., Ltd., Osaka, Japan) under the following conditions: 30 cycles of denaturation at $94^{\circ} \mathrm{C}$ for $30 \mathrm{~s}$, annealing at $45^{\circ} \mathrm{C}$ for $5 \mathrm{~s}$, and extension at $74^{\circ} \mathrm{C}$ for $10 \mathrm{~s}$. When PCR amplification under these conditions was not successful, PCR was performed as follows: initial denaturation at $94^{\circ} \mathrm{C}$ for $2 \mathrm{~min}$, five cycles of denaturation at $94^{\circ} \mathrm{C}$ for $30 \mathrm{~s}$, annealing at $48^{\circ} \mathrm{C}$ for 1 min $30 \mathrm{~s}$, and extension at $72^{\circ} \mathrm{C}$ for $1 \mathrm{~min}$, followed by 35 cycles of denaturation at $93^{\circ} \mathrm{C}$ for $30 \mathrm{~s}$, annealing at $51^{\circ} \mathrm{C}$ for $1 \mathrm{~min} 30 \mathrm{~s}$, and extension at $72^{\circ} \mathrm{C}$ for $1 \mathrm{~min}$, and final extension at $72^{\circ} \mathrm{C}$ for $7 \mathrm{~min}$. Primers used in this study are described in Table 2. PCR products were purified using a QIAquick ${ }^{\circledR}$ PCR Purification Kit (QIAGEN GmbH, Hilden, Germany).

Direct sequencing of the purified double-strand PCR products was performed using a BigDye ${ }^{\circledR}$ Terminator v1.1 Cycle Sequencing Kit (Applied Biosystems Inc., California, USA) and the same set of primers used for PCR on ABI PRISM 377 and 377XL DNA sequencers (Applied Biosystems Inc., California, USA) according to the manufacturer's directions. DNA sequences were aligned with DNASIS-Mac v3.2 (Hitachi Software Engineering Co., Ltd., Tokyo, Japan) and MEGA 6.0 [20]. All sequences are registered in DDBJ (accession numbers LC062961-LC063128). Comparison between ND4 sequences of A. pacifica determined in this study and the corresponding database sequence of Mytilus edulis revealed the lack of three consecutive nucleotides encoding 34th amino acid of A. pacifica. Similarly, comparison between ND4 sequences of B. geikotsucola in this study and the corresponding database sequence in $M$. edulis revealed the lack of three consecutive nucleotides encoding 41th amino acid of B. geikotsucola. 
Table 2. Primers used for amplification of the mitochondrial NADH dehydrogenase subunit 4 gene and their sequence.

\begin{tabular}{llll}
\hline Adipicola pacifica & & \multicolumn{2}{l}{ Benthomodiolus geikotsucola } \\
\hline Sense ArgBL & 5'-caagacccttgatttcggctca-3' & Sense tori-6S & 5'-ttcgcttcgtttacaccgaagaagt-3' \\
Antisense NAP2H & 5'-tggagcttctacgtgrgcttt-3' & Antisense tori-6A & 5'-agtcaactaaaccctatcaccctct-3' \\
\hline
\end{tabular}

\subsection{Population Genetic Analysis}

Population genetic analysis was performed essentially as described previously [14]. The minimum spanning tree that presents relationships among haplotypes was constructed using MEGA 6.0. Genetic differentiation $\left(F_{\mathrm{st}}\right)$ and bidirectional mean rate of gene flow (Nm; the virtual average number of migrants exchanged per generation) were calculated using Arlequin 3.5.1.2 [21]. The significance of $F_{\text {st }}$ was evaluated by calculating $1 \times 10^{4}$ values. The mismatch distribution was constructed using Arlequin 3.5.1.2, and goodness-of-fit test was used to evaluate discrepancy between observed and model values of the mismatch distribution. The expansion time $(\tau=2 u t)$, obtained from the mismatch distribution, is proportional to the number of generations $(t)$ since the population size at equilibrium entered a demographic expansion phase, although the mutation rate $(u)$ of mytilid mussels is unknown.

\section{Results}

The minimum spanning trees were constructed using 100 specimens of A. pacifica (Figure 2) and 40 specimens of B. geikotsucola (Figure 3) to compare annual changes in genetic structures. In A. pacifica, 27 haplotypes were detected. The haplotype of the greatest majority was shared by 29 (29.0\%) specimens from CN in 2003, 2004, 2005, 2007, and 2010. In B. geikotsucola, four haplotypes were detected. The haplotype of the greatest majority was shared by 34 (85.0\%) specimens from TS in 1993 and 2005. Two other haplotypes were found in 1993 and another haplotype in 2005. Genetic structures among sampling sites were compared using the minimum spanning tree constructed from 128 specimens of A. pacifica (Figure 4). The haplotype of the greatest majority was shared by 41 (32.0\%) specimens from CN, NS, and SB.

In $A$. pacifica $\mathrm{CN}$ collections, the values of $F_{\text {st }}$ approximated zero in pairwise comparisons, but a significant genetic differentiation ( $p=0.03683$ ) was found between specimens collected in 2003 and 2010 (Table 3). There was no significant genetic differentiation between all combinations except the above combination $(p>0.05)$, showing almost no annual change in genetic structure. In B. geikotsucola, the $F_{\mathrm{st}}$ value was ca. 0.11 and there was no significant genetic differentiation between specimens collected in 1993 and 2005 (Table 4). Gene diversity of A. pacifica from CN in 2003, 2004, 2005, and 2007 ranged between 0.83 and 0.90, it was smaller (0.77) in the 2010 collection (Table 5). Nucleotide diversity was between 0.0035 and 0.0047 in 2003, 2004, 2005, and 2007 collections, whereas it was smaller $(0.0023)$ in the 2010 collection. The gene and nucleotide diversities of B. geikotsucola were smaller in 2005 than in 1993 (Table 6).

Since there was almost no annual change in genetic structure, data from the annual collections were combined in CN. The values of Fst approximated zero in pairwise comparisons and there was no significant genetic differentiation between specimens from CN, NS, and SB (Table 7). The values of Nm were more than one between all combinations, indicating extensive gene flow among CN, NS, and SB. Gene diversities from CN $(0.86)$ and NS (0.80) were higher than that from SB (0.64) (Table 5). The nucleotide diversity from CN (0.0039) was higher than that from SB (0.0029), and that from NS (0.0033) was intermediate between two.

Mismatch distributions of A. pacifica from CN, NS, and SB are shown in Figure 5. Goodness-of-fit test showed no significant difference between the observed and expected values $(0.978,0.789$, and 0.059 for $\mathrm{CN}$, NS, and SB, respectively). The expansion time decreased in the order of SB (2.395), CN (1.873), and NS (1.719), showing that the number of generations decreased in the same order.

\section{Discussion}

There was almost no annual genetic change among A. pacifica specimens from $\mathrm{CN}$, suggesting that the population propagated from the founder and has maintained its unperturbed genetic composition by inbreeding. Alternatively, the population has been supplied repeatedly with many propagules of stable genetic composition from 


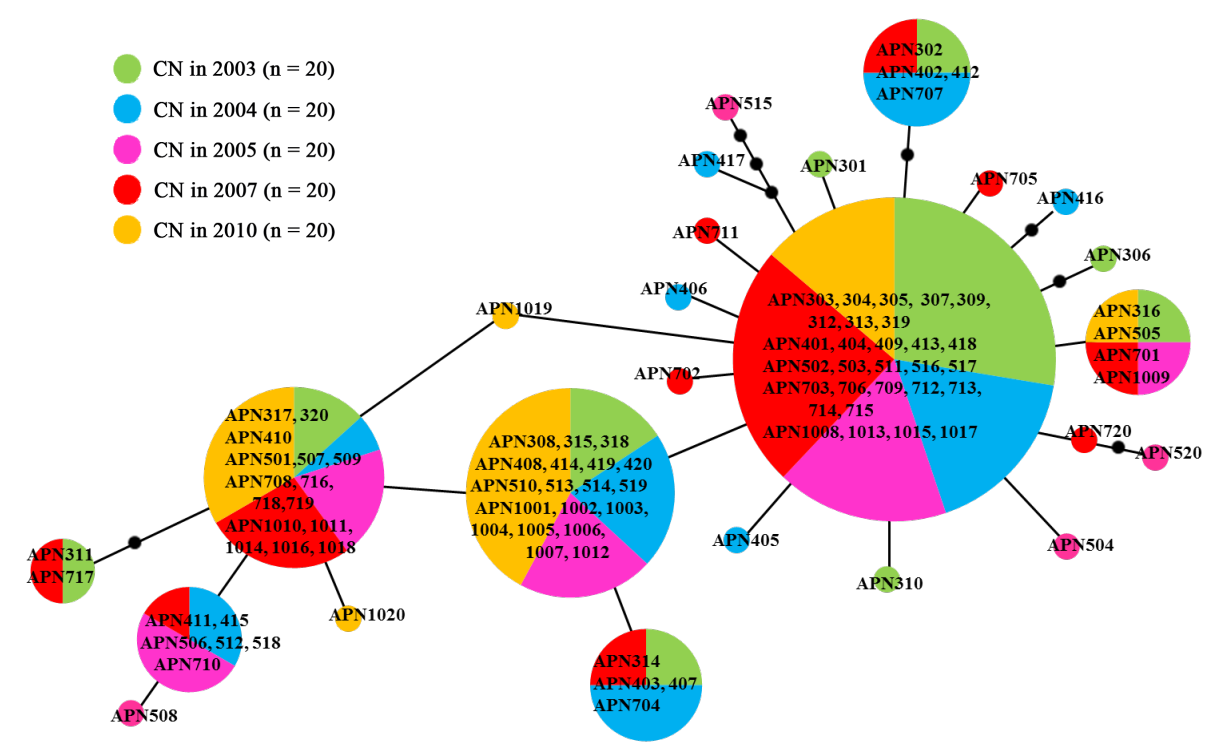

Figure 2. Minimum spanning tree of Adipicola pacifica samples collected from Japanese waters off Cape Noma (CN) in 2003, 2004, 2005, 2007, and 2010. Colored circles indicate haplotypes and their dimensions are proportional to the number of individuals. Black circles on lines indicate hypothetical haplotypes not found in this study. Samples collected in 2003, 2004, 2005, 2007 and 2010 are colored in green, blue, pink, red, and orange, respectively.

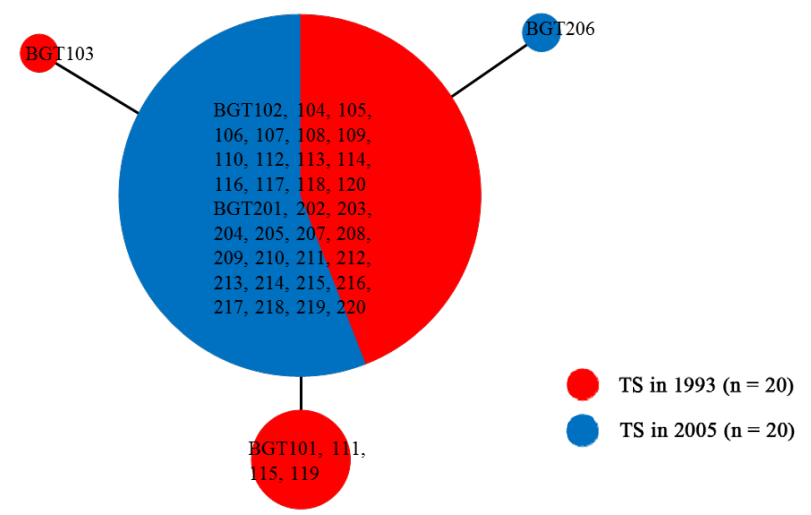

Figure 3. Minimum spanning tree of Benthomodiolus geikotsucola samples from Japanese waters in the Torishima Seamount in 1993 and 2005. Colored circles indicate haplotypes and their dimensions are proportional to the number of individuals. Black circles on lines indicate hypothetical haplotypes not found in this study. Samples collected in 1993 and 2005 are colored red and blue, respectively.

Table 3. Genetic differentiation $\left(F_{\text {st }}\right)$ and $F_{\text {st }} p$ values of Adipicola pacifica samples collected from Japanese waters off Cape Noma (CN) in 2003, 2004, 2005, 2007, and 2010.

\begin{tabular}{rccccc}
\hline & $F_{\text {st }}$ & CN in 2003 & CN in 2004 & CN in 2005 & CN in 2007 \\
\hline st value & & & -0.02086 & 0.03613 & -0.02675 \\
CN in 2004 & $0.83695 \pm 0.0031$ & & 0.00819 & -0.01540 & 0.00423 \\
CN in 2005 & $0.09742 \pm 0.0030$ & $0.28126 \pm 0.0044$ & & 0.00669 \\
CN in 2007 & $0.93248 \pm 0.0028$ & $0.69944 \pm 0.0043$ & $0.29908 \pm 0.0045$ & 0.04655 \\
CN in 2010 & $0.03683 \pm 0.0020^{*}$ & $0.08306 \pm 0.0027$ & $0.33036 \pm 0.0046$ & $0.10781 \pm 0.0031$ \\
\hline
\end{tabular}

$F_{\text {st }}$, above the diagonal; $F_{\text {st }} p$ value, below the diagonal. An asterisk indicates significant difference. 


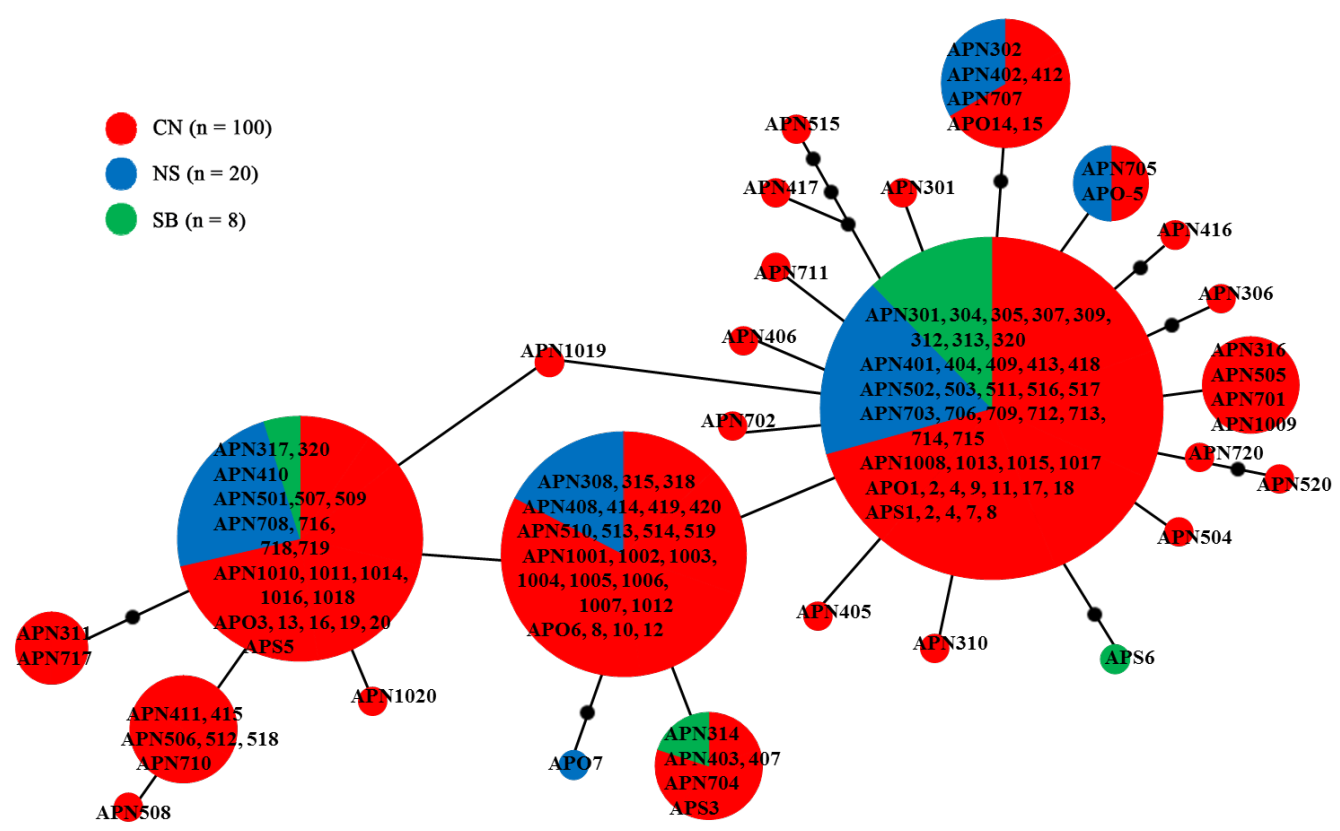

Figure 4. Minimum spanning tree of Adipicola pacifica samples from Japanese waters off Cape Noma (CN) and in Nansei-Shoto Trench (NS) and Sagami Bay (SB). Colored circles indicate haplotypes and their dimensions are proportional to the number of individuals. Black circles on lines indicate hypothetical haplotypes not found in this study. Samples collected in CN, NS, and SB are colored red, blue, and green, respectively.

Table 4. Genetic differentiation $\left(F_{\text {st }}\right)$ and $F_{\text {st }} p$ values of Benthomodiolus geikotsucola samples collected from Japanese waters in the Torishima Seamount in 1993 and 2005.

\begin{tabular}{cccc}
\hline & $F_{\text {st }}$ & 1993 & 2005 \\
\hline$F_{\text {st }} p$ value & & & 0.10526 \\
& 1993 & $0.100986 \pm 0.0032$ & \\
\hline
\end{tabular}

$F_{\text {st, }}$ above the diagonal; $F_{\text {st }} p$ values, below the diagonal.

Table 5. Genetic diversities of Adipicola pacifica samples collected from Japanese waters off Cape Noma (CN) in 2003, 2004, 2005, 2007, 2010, and in total, and in the Nansei-Shoto Trench (NS) and Sagami Bay (SB).

\begin{tabular}{ccc}
\hline & Gene diversity & Nucleotide diversity \\
\hline CN in 2003 & $0.8316 \pm 0.0751$ & $0.003548 \pm 0.002403$ \\
CN in 2004 & $0.9000 \pm 0.0428$ & $0.004373 \pm 0.002831$ \\
CN in 2005 & $0.8842 \pm 0.0416$ & $0.004716 \pm 0.003007$ \\
CN in 2007 & $0.8579 \pm 0.0645$ & $0.004105 \pm 0.002693$ \\
CN in 2010 & $0.7684 \pm 0.0624$ & $0.002283 \pm 0.001733$ \\
CN in total & $0.8554 \pm 0.0220$ & $0.003850 \pm 0.002455$ \\
NS & $0.8000 \pm 0.0537$ & $0.003259 \pm 0.002252$ \\
SB & $0.6429 \pm 0.1841$ & $0.002910 \pm 0.002249$ \\
\hline
\end{tabular}

Table 6. Genetic diversities of Benthomodiolus geikotsucola samples collected from Japanese waters in the Torishima Seamount in 1993 and 2005.

\begin{tabular}{ccc}
\hline & Gene diversity & Nucleotide diversity \\
\hline 1993 & $0.4158 \pm 0.1157$ & $0.001087 \pm 0.001135$ \\
2005 & $0.1000 \pm 0.0880$ & $0.000249 \pm 0.000493$ \\
\hline
\end{tabular}




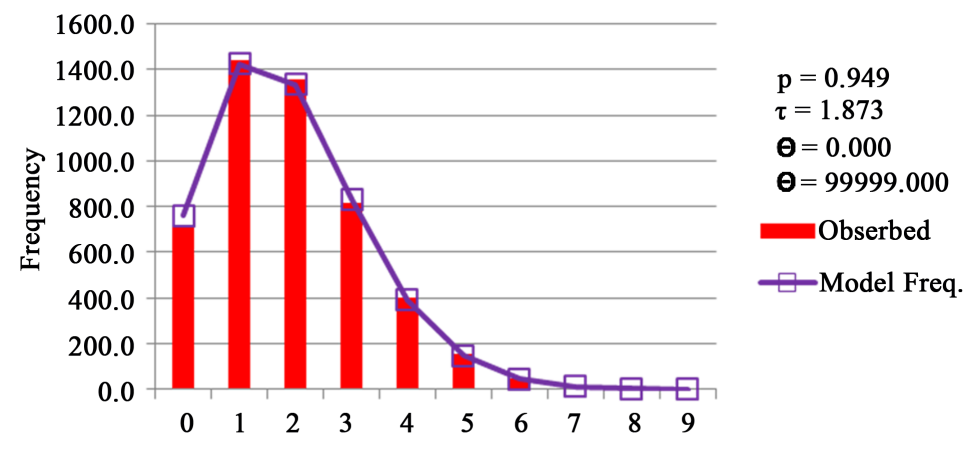

(a)

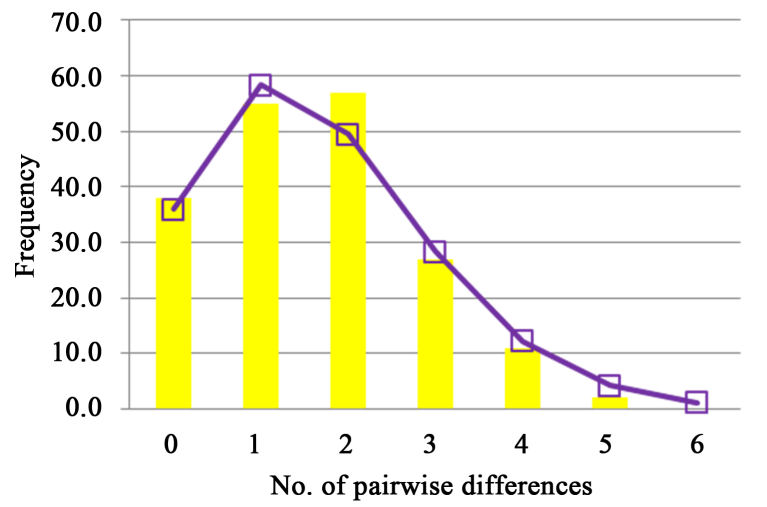

$$
\begin{aligned}
p & =0.789 \\
\tau & =1.719 \\
\Theta & =0.000 \\
\Theta & =46.509 \\
& \text { Obserbed } \\
&
\end{aligned}
$$

(b)

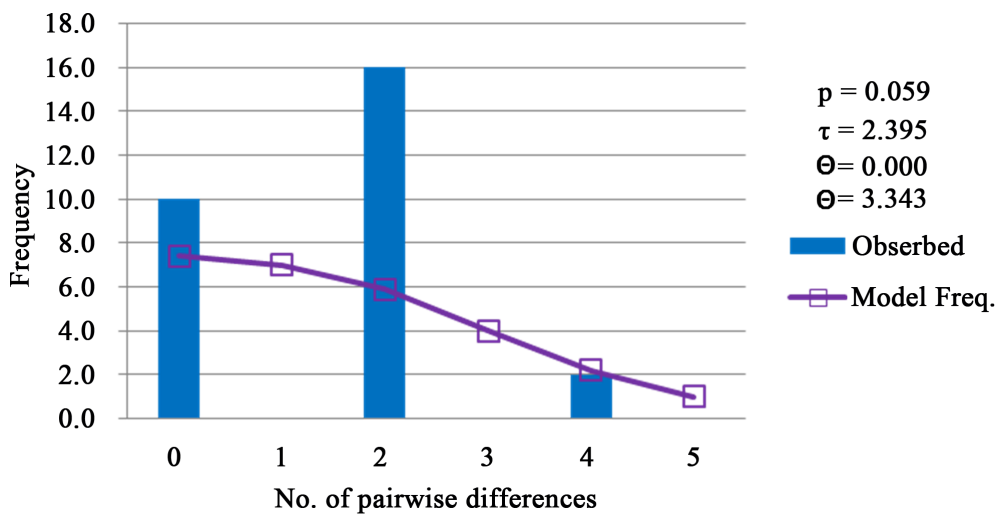

(c)

\begin{tabular}{|c|c|c|c|c|}
\hline$F_{\mathrm{st}}\left(F_{\mathrm{st}} p\right.$ value $)$ & $\mathrm{Nm}$ & $\mathrm{CN}$ & NS & SB \\
\hline $\mathrm{CN}$ & & & $\inf$ & $\inf$ \\
\hline NS & & $-0.01655(0.89249 \pm 0.0029)$ & & 46.97674 \\
\hline SB & & $-0.00067(0.40145 \pm 0.0049)$ & $0.01053(0.32541 \pm 0.0060)$ & \\
\hline
\end{tabular}

Figure 5. Mismatch distribution based on 491-bp-long sequences of the mitochondrial NADH dehydrogenase subunit 4 gene in Adipicola pacifica. (a) off Cape Noma; (b) Nansei-Shoto Trench; (c) Sagami Bay.

Table 7. Genetic differentiation $\left(F_{\mathrm{st}}\right), F_{\mathrm{st}} p$ value, and gene flow $(\mathrm{Nm})$ of Adipicola pacifica samples collected from Japanese waters off Cape Noma (CN) and in the Nansei-Shoto Trench (NS) and Sagami Bay (SB).

Nm, above the diagonal; $F_{\text {st }}$ and $F_{\text {st }} p$ values in parentheses, below the diagonal. 
a large, unknown population. However, the 2010 collection had higher $F_{\text {st }}$ values to the 2004 and 2007 collections (Table 3). Significant genetic differentiation was found between the 2003 and 2010 collections, in particular, suggesting that the genetic composition changed in 2010 probably due to the decline in the population size, as evidenced by the loss of genetic diversity. The decline in population size may have been caused by waste of whale oil which fuels the whale bone community.

There was no genetic differentiation among specimens from CN, NS, and SB, suggesting that A. pacifica has high gene flow and therefore high dispersal ability. As mentioned above, the genetic composition of the 2010 $\mathrm{CN}$ collection was somewhat different from that of other CN collections (Table 3). We reassessed genetic differentiation among the specimens from CN, NS, and SB by excluding the $2010 \mathrm{CN}$ collection and combining the 2003, 2004, 2005, and $2007 \mathrm{CN}$ collections together. The $F_{\text {st }}$ values approximated zero and Nm values were very high $\left(F_{\mathrm{st}}=-0.01655\right.$ and $\mathrm{Nm}=$ infinity between $\mathrm{CN}$ and $\mathrm{NS},-0.00067$ and infinity between $\mathrm{CN}$ and $\mathrm{SB}$, -0.01053 and 46.98 between NS and SB). The reassessed $F_{\text {st }}$ and Nm values indicate high dispersal ability of $A$. pacifica. Other studies also suggest high dispersal ability of organic-fall organisms. The siboglinid bone-eating worm Osedax presented almost no genetic difference between specimens obtained from Monterey Bay and Sagami Bay, suggesting trans-Pacific dispersal [22]. Distinct genetic structure of the mytilid mussel, Idas iwaotakii, was not found between the specimens from New Caledonia, Vanuatu, and Papua New Guinea, locations that are from 500 to $2400 \mathrm{~km}$ apart [23].

The "evolutionary stepping-stone hypothesis" is supported in mytilids [16] [17]. In order to adapt to the deep sea, organisms must acquire tolerance to high pressure and low temperature. Symbiosis with chemosynthetic bacteria is one of the best strategies to acquire energy under deep-sea conditions of poor nutrient availability due to lack of photosynthesis. Moreover, organisms must acquire the dispersal ability to reach and utilize patchily distributed deep-sea vents and seeps. Ancestors inhabiting organic falls such as whale bones and sunken wood may have facilitated subsequent colonization of deep-sea vents and seeps.

Phylogenetic analyses of mytilid mussels positioned A. pacifica as an outgroup to Bathymodiolus, which are obligate inhabitants of deep-sea vents and seeps. High dispersal ability of A. pacifica enables their colonization and utilization of organic falls. Whale bones artificially set at CN were colonized by two Adipicola species, $A$. pacifica and A. crypta. The former tends to inhabit bones positioned over the sediment, while the latter bones buried into the sediment [8]. A. crypta was not found on the whale and cow bones located in NS and SB. This indicates that, unlike A. pacifica, A. crypta may not have high dispersal ability, and that bone-associated and probably wood-associated mytilids may not always have high dispersal ability, which needs to be further tested by genetic studies. Deep-sea Bathymodiolus mussels have small-sized eggs and planktotrophic development, which allows them to disperse long distances. Our preliminary results showed that the egg size of A. pacifica was not different from that of $A$. crypta, and nearly identical to that of Bathymodiolus. Therefore, we cannot explain the difference in the dispersal ability between A. pacifica and A. crypta. On the other hand, bones at NS and SB may not have represented an environment suitable for survival of A. crypta. The life style, especially dispersal strategy of mytilids inhabiting organic falls such as A. crypta, warrants further studies. Population genetic analyses of more mytilid mussels including organic fall and shallow water species are needed to test our hypothesis that high dispersal ability was facilitated by organic falls.

According to the $\tau$ values, the SB population is the oldest and the NS population is the youngest among the studied populations, suggesting that A. pacifica dispersed southward from SB into NS via CN. Larvae of $A$. pacifica may be transported passively by the currents. However, dispersal from SB into NS seems unlikely because the strong Kuroshio Current in the west Pacific flows northward. Analysis of more specimens from SB is required in order to elucidate the history of A. pacifica expansion (we could use only eight specimens from SB). The $\tau$ value (2.062) of A. pacifica excluding the $2010 \mathrm{CN}$ collection was also intermediate between those of NS and SB.

The $F_{\text {st }}$ values indicate that $B$. geikotsucola from TS did not undergo significant genetic differentiation during 12 years, from 1993 to 2005. The present result suggests that the population has kept its genetic composition either by inbreeding or by a repeated supply of numerous propagules from a large, unknown population. It is likely that genetic transition proceeds at a slower pace in deeper sea waters such as TS than in the shallower sea waters such as CN. The community at TS (4020 m depth) is one of the deepest whalebone-associated communities. Whale bones of $\mathrm{CN}$ were eroded and covered with sediments very rapidly over the 8-year period, whereas those at TS showed only a small change (erosion) over the 12-year period [JAMSTEC cruise reports, YK-05-09 leg 1]. Moreover, B. geikotsucola had only four haplotypes, while 27 haplotypes were recognized in A. pacifica 
collections. This may also indicate slower genetic transition in the deeper sea. We collected samples of $B$. geikotsucola only from TS; hence dispersal ability of B. geikotsucola was not investigated in this study. However, since organic falls have not been discovered in the vicinity of the sampling site, the founder of B. geikotsucola may have been transported long distance to colonize the bones located in TS. This suggests that B. geikotsucola has high dispersal ability. Genetic diversities of B. geikotsucola in 2005 were lower than those in 1993. It suggests the decline in the population size, while infrequent haplotypes may be detected by analysis of more specimens.

\section{Conclusion}

Organisms in deep-sea vents and seeps must have high dispersal ability, because vents and seeps are patchily distributed. We hypothesize that high dispersal ability was acquired in organic falls to colonize deep sea. In this study, we showed by genetic similarities among specimens from three localities that one of the organic-fall mytilid mussels, A. pacifica, has high dispersal ability. However, more species and more specimens from different localities need to be analyzed to test the hypothesis. We also showed stable genetic structures of organic-fall mussels, A. pacifica and B. geikotsucola, for about a decade, suggesting that they have propagated from the founder and inbred to maintain their genetic composition or they have been supplied repeatedly with many propagules of stable genetic composition from large sources.

\section{Acknowledgements}

The authors would like to express thanks to the operation teams of the submersibles and the officers and crew of the support vessels for their help in collecting the samples. This study was supported in part by a grant from the Ministry of Education, Culture, Sports, Science and Technology of Japan (No. 25440204).

\section{References}

[1] Corliss, J.B. and Ballard, R.D. (1977) Oases of Life in the Cold Abyss. National Geographic, 152, 440-453.

[2] Lonsdale, P. (1977) Clustering of Suspension-Feeding Macrobenthos near Abyssal Hydrothermal Vents at Oceanic Spreading Centers. Deep Sea Research, 24, 857-863. http://dx.doi.org/10.1016/0146-6291(77)90478-7

[3] Paull, C.K., Hecker, B., Commeau, R., Freeman-Lynde, R.P., Neumann, C., et al. (1984) Biological Communities at the Florida Escarpment Resemble Hydrothermal Vent Taxa. Science, 226, 965-967. http://dx.doi.org/10.1126/science.226.4677.965

[4] Kennicutt II, M.C., Brooks, J.M., Bidigare, R.R., Fay, R.A., Wade T.L., et al. (1985) Vent-Type Taxa in a Hydrocarbon Seep Region on the Louisiana Slope. Nature, 317, 351-353. http://dx.doi.org/10.1038/317351a0

[5] Smith, C.R., Kukert, R.A., Wheatcroft, R.A., Jumars, P.A. and Deming, J.W. (1989) Vent Fauna on Whale Remains. Nature, 341, 27-28. http://dx.doi.org/10.1038/341027a0

[6] Smith, C.R. and Baco, A.R. (2003) Ecology of Whale Falls at the Deep-Sea Floor. Oceanography and Marine Biology, an Annual Review, 41, 311-354.

[7] Okutani, T., Fujiwara, Y., Fujikura, K., Miyake, H. and Kawato, M. (2003) A Mass Aggregation of the Mussel Adipicola pacifica (Bivalvia, Mytilidae) on Submerged Whale Bones. The Malacological Society of Japan, 63, 61-64.

[8] Fujiwara, Y., Kawato, M., Yamamoto, T., Yamanaka, T., Sato-Okoshi, W., et al. (2007) Three-Year Investigations into Sperm Whale-Fall Ecosystems in Japan. Marine Ecology, 28, 219-232. http://dx.doi.org/10.1111/j.1439-0485.2007.00150.x

[9] Naganuma, T., Wada, H. and Fujioka, K. (1996) Biological Community and Sediment Fatty Acids Associated with the Deep-Sea Whale Skeleton at the Torishima Seamount. Journal of Oceanography, 52, 1-15. http://dx.doi.org/10.1007/BF02236529

[10] Okutani, T. and Miyazaki, J.-I. (2007) Benthomodiolus geikotsucola n. sp.: A Mussel Colonizing Deep-Sea Whale Bones in the Northwest Pacific (Bivalvia: Mytilidae). Venus, 66, 49-55.

[11] Jollivet, D. (1996) Specific and Genetic Diversity at Deep-Sea Hydrothermal Vents: An Overview. Biodiversity and Conservation, 5, 1619-1653. http://dx.doi.org/10.1007/BF00052119

[12] Hashimoto, J. and Okutani, T. (1994) Four New Mytilid Mussels Associated with Deepsea Chemosynthetic Communities around Japan. Venus, 53, 61-83.

[13] Miyazaki, J.-I., Beppu, S., Kajio, S., Dobashi, A., Kawato, M., et al. (2013) Dispersal Ability and Environmental 
Adaptability of Deap-Sea Mussels Bathymodiolus (Mytilidae: Bathymodiolinae). Open Journal of Marine Science, $\mathbf{3}$, 31-39. http://dx.doi.org/10.4236/ojms.2013.31003

[14] Kyuno, A., Shintaku, M., Fujita, Y., Matsumoto, H., Utsumi, M., et al. (2009) Dispersal and Differentiation of DeepSea Mussels of the Genus Bathymodiolus (Mytilidae, Bathymodiolinae). Journal of Marine Biology, 2009, Article ID: 625672.

[15] Distel, D.L., Baco, A.R., Chuang, E., Morrill, W., Cavanaugh, C. and Smith, C.R. (2000) Marine Ecology: Do Mussels Take Wooden Steps to Deep-Sea Vents? Nature, 403, 725-726. http://dx.doi.org/10.1038/35001667

[16] Miyazaki, J.-I., de Oliveria Martins, L., Fujita, Y., Matsumoto, H. and Fujiwara, Y. (2010) Evolutionary Process of Deep-Sea Bathymodiolus Mussels. PLoS ONE, 5, e10363. http://dx.doi.org/10.1371/journal.pone.0010363

[17] Lorion, J., Kiel, S., Faure, B., Kawato, M., Ho, S.Y., et al. (2013) Adaptive Radiation of Chemosymbiotic Deep-Sea Mussels. Proceedings of the Royal Society of London B, 280, 1243. http://dx.doi.org/10.1098/rspb.2013.1243

[18] Fujioka, K., Wada, H. and Okano, H. (1993) Torishima Whale Bone Deep-Sea Animal Community AssemblageNew Finding by Shinkai 6500. Journal of Geography, 102, 507-517. (In Japanese)

[19] Wada, H. (1993) Torishima Whale Bone Animal Community (TOWBAC). Shizuoka Chigaku (Shizuoka Geology), 67, 1-3. (In Japanese with color plates).

[20] Tamura, K., Stecher, G., Peterson, D., Filipski, A. and Kumar, S. (2013) MEGA6: Molecular Evolutionary Genetics Analysis Version 6.0. Molecular Biology and Evolution, 30, 2725-2729. http://dx.doi.org/10.1093/molbev/mst197

[21] Excoffier, L. and Lischer, H.E.L. (2010) Arlequin Suite Ver 3.5: A New Series of Programs to Perform Population Genetics Analyses under Linux and Windows. Molecular Ecology Resources, 10, 564-567. http://dx.doi.org/10.1111/j.1755-0998.2010.02847.x

[22] Amon, D.J. (2013) Bone-Eating Worms and Wood-Eating Bivalves: Characterising the Ecology of Deep-Sea Organic Falls from Multiple Ocean Basins. Ph.D. Thesis, University of Southampton Press, Southampton, 1-186.

[23] Thubaut, J., Corbari, L., Gros, O., Duperron, S., Couloux, A., et al. (2013) Integrative Biology of Idas iwatakii (Habe, 1958), a “Model Species” Associated with Sunken Organic Substrates. PLoS ONE, 8, e69680.

http://dx.doi.org/10.1371/journal.pone.0069680 